\title{
Assessing the Effect of Weak and Strong Acids as Electrolytes in the Removal of Cesium by Soil Electrokinetic Remediation
}

\author{
Rudy Syah Putra ${ }^{1,2, *}$, Alfi Ihda Amalia ${ }^{1}$, and Naila Zahrotul Jannah ${ }^{1}$ \\ ${ }^{1}$ Department of Chemistry, Faculty of Mathematics and Natural Sciences, Universitas Islam Indonesia, \\ Jl. Kaliurang km. 14, Yogyakarta 55584, Indonesia \\ ${ }^{2}$ Environmental Remediation Research Group, Department of Chemistry, Faculty of Mathematics and Natural Sciences, \\ Universitas Islam Indonesia, Jl. Kaliurang km. 14, Yogyakarta 55584, Indonesia
}

${ }^{*}$ Corresponding author:

tel: $+62-81327709104$

email: rudy.syahputra@uii.ac.id

Received: January 8, 2020

Accepted: May 28, 2020

DOI: $10.22146 / \mathrm{ijc} .53283$

\begin{abstract}
The removal of cesium from artificially contaminated soil using electrokinetic remediation with nitric and acetic acid as electrolytes had been evaluated. In this study, uncontaminated soil was taken from four different sampling points (i.e., A, B, C, and D) in Kotagede, Yogyakarta, Indonesia. All samples were prepared as cesium contaminated soil (100 mg CsCl/kg soil), which have similar physicochemical characteristics with Fukushima soil, Japan. The electrokinetic remediation (EKR) was conducted using a graphite electrode in a constant voltage of $1.0 \mathrm{Vcm}^{-1}$ for 7 days without electrolyte $\mathrm{pH}$ control, with 1.0 M nitric and acetic acid as electrolytes. The current profile during the EKR was recorded by a data logger for every $10 \mathrm{~min}$. The remaining cesium in the soil was measured by a flame atomic absorption spectrophotometer at a wavelength of $852.1 \mathrm{~nm}$. The results showed that the type of acid used in the experiments affected the removal of cesium. The highest cesium removal was achieved when nitric acid was used in the experiment and then followed by acetic acid. For all acids, the removal ability of cesium from soil was in the following order: soil $C>$ soil $A>$ soil $D>$ soil B.
\end{abstract}

Keywords: cesium; electrokinetic remediation; Fukushima; soil

\section{- INTRODUCTION}

The rapid growth of the economic sector has caused Indonesia to experience a serious power shortage. Power consumption grows as the industry grows, which means that there must be more electricity to be produced. By an industrial production growth rate of $10.5 \%$, the electricity demand is estimated to reach 450 billion kWh in 2026 [1]. Under these circumstances, it is hardly a surprise that nuclear plants would not be left out of the government plan for the electrification of the country. On November $30^{\text {th }}, 2011$, the Minister of State-Owned Enterprises of the Republic of Indonesia had adopted a long-term plan for the development of nuclear energy in Indonesia [2]. Fear of accidents in nuclear power plants is a major factor that led many to oppose the construction of nuclear power plants in Indonesia. The fear comes from the history of several cases involving nuclear energy, including the
Chernobyl and Fukushima accidents [3-4], which led to adsorption of Cs-137 into the soil that persisted for many years resulting in the restriction of the land to be reused as agricultural land. In addition, the development of a nuclear power plant has a possibility to release radionuclide to the environment that imposes a strict requirement on the development of a cost-effective method to remove radionuclides from contaminated soils [5]. Several technologies have been developed for remediation of contaminated soil, which includes bioremediation [6], thermal desorption [7], soil leaching [8], and electrokinetic remediation [9].

Electrokinetic remediation is one of the promising technologies that can be used to separate and extract heavy metals, radionuclides, and organic contaminants from saturated or unsaturated soils, sludges and sediments, and groundwater. When an electric field is applied to the soil, the water electrolysis induce $\mathrm{H}^{+}$and 
$\mathrm{OH}^{-}$ions at the anode and cathode electrode. In addition, the electrokinetic transport phenomena include the movement of water (electroosmosis), ions and polar molecules (electromigration), and charged solid particles (electrophoresis) formed between two electrodes [5,9]. These processes, together, are referred to as electrokinetics and can be used to remediate contaminated soil in place without excavation.

The advantages of electrokinetic remediation have been reported in numerous studies [3,9] as follows (1) applicability to specific low permeability contaminated soils that have high adsorption of pollutants (e.g., clays, silts, and layers) and groundwater. These soils are resistant to clean using common in-situ remedial techniques, such as pump-and-treat method which require a hydraulic gradient to be efficient in the process; (2) flow direction of the fluid in the soil is highly controlled, unlike in the soil flushing process; (3) can be used in a wide range removal of contaminants such as heavy metals, radionuclides, and organic compounds; and (4) the treatment has a low electric power consumption.

The objective of this study is to evaluate the feasibility of the electrokinetic remediation on the removal of cesium from artificially contaminated soils from Kotagede, Yogyakarta, Indonesia. These soil samples have similar physicochemical characteristics with Fukushima soil. In addition, the investigation of acids effect (e.g., nitric acid and acetic acid) as enhancing agents, and the optimum condition for the efficient removal were also evaluated. Therefore, a safer experiment was carried out for feasibility application in a real radionuclide contaminated soil in the future. Obtained results from this study can be used to predict the possible application of the technology for soil remediation at actual conditions in Fukushima.

\section{- EXPERIMENTAL SECTION}

\section{Materials}

Cesium chloride was purchased from Wako Chemical, Japan, while nitric and acetic acid were purchased from Merck, Germany, without further purification.

\section{Instrumentation}

Minerals characteristic in the soil were measured by X-ray benchtop diffractometer (Bruker D2 Phaser, Germany) using $\mathrm{CuKa}$ radiation over a $2 \theta$ range from 5 to $80^{\circ}$ with a step size of $0.02^{\circ}$ at a scanning speed of $0.4^{\circ} / \mathrm{sec}$. Reference patterns from the ICDD PDF database were used for qualitative phase identification of minerals in each soil. The remaining concentration of cesium in the soil was extracted using concentrated nitric acid, and then cesium concentration in the solution was determined by flame atomic absorption spectrophotometry (Perkin-Elmer, PinAAcle 900T, USA) at wavelength of $852.1 \mathrm{~nm}$.

\section{Procedure}

\section{Collection and preparation of soil}

Clean soil samples were collected from four different locations at Kotagede district in Yogyakarta, Indonesia (i.e., GPS for soil A: S07 $49,291^{\prime} \mathrm{E} 110^{\circ} 23,996^{\prime}$, soil B: $S 07^{\circ} 49,627^{\prime} \mathrm{E} 110^{\circ} 23,895^{\prime}$, soil C: $\mathrm{S} 07^{\circ} 49,578^{\prime}$ E110 23,878', soil D: S07 $49,589^{\prime}$ E1 10 $\left.23,713^{\prime}\right)$. Measurement of the soil properties was described in a reported paper elsewhere [10]. All soils from Kotagede were artificially contaminated by $100 \mathrm{mg} / \mathrm{kg}$ cesium (i.e., $\mathrm{CsCl}$ salts) and treated by five cycles ( 1 cycle for 2 weeks) of saturation process and air-dried before being aged for five months.

For Fukushima soil, Japan, the samples were collected from two different locations, which were Sarukubo soil, Kawamata (N 37.67127 E 140.64745), and Haramaci soil, Minamisoma (N 37.63820 E 141.00637). At the time of sampling in October 2011, the soil had been contaminated with radiocesium of about $0.3 \mu \mathrm{S} / \mathrm{h}$ for the Sarukubo soil and $0.1 \mu \mathrm{S} / \mathrm{h}$ for the Haramaci soil.

\section{Electrokinetic remediation (EKR) treatment}

A series of bench-scale EKR experiments were conducted according to a previous paper [10]. The electrokinetic remediation setup is shown in Fig. 1. The testing box consists of three major parts, a soil chamber and two electrode compartments. The EKR reactor contained $200 \mathrm{~g}$ of soil and was well connected to the electrode in both ends. Graphite electrodes were used 


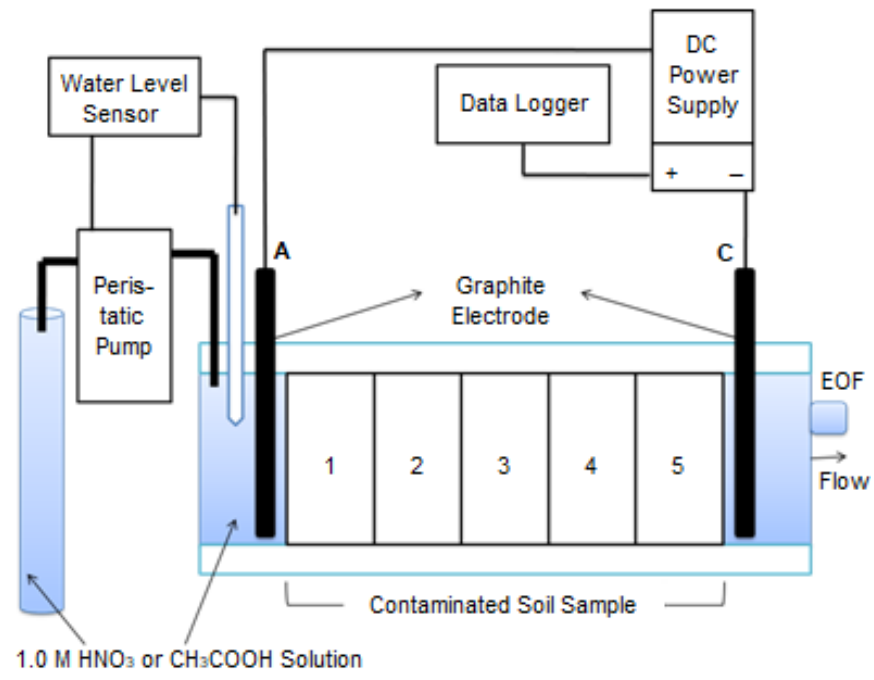

Fig 1. Electrokinetic remediation set up reactor used in this study

for the cathode (C) and anode (A). In this study, nitric acid and acetic acid were used as an electrolyte. A $1.0 \mathrm{Vcm}^{-1}$ of potential gradient was applied for 7 days of experiment [10]. The electric currents were monitored by a data logger (GL200A, Graphtec USA) for every $10 \mathrm{~min}$. After the experiment, the soil was sectioned into five parts, and the soil $\mathrm{pH}$ was measured by mixing $0.5 \mathrm{~g}$ soil with $10 \mathrm{~mL}$ of distilled water and stirring for $30 \mathrm{~min}$. The remaining cesium was extracted from soil by mixing about $0.5 \mathrm{~g}$ soil with $10 \mathrm{~mL}$ of $65 \% \mathrm{HNO}_{3}$ and then shaking it for $24 \mathrm{~h}$.

\section{- RESULTS AND DISCUSSION}

\section{Soil Characterization}

The similarity of Kotagede and Fukushima soils were in terms of soil texture, soil properties, and mineral content. All soil samples from Kotagede have the same texture with Fukushima soil and was characterized as sandy loam, and they all have high CEC values and organic matter content. In addition, soils $\mathrm{A}$ and $\mathrm{C}$ were relatively easy to acidify compared to soils B and D [10]. Qualitatively, the mineralogy of soil from Kotagede was identified by comparing $2 \theta$ diffractograms of reported studies [11]. The major mineral characteristic of soils $A$, $\mathrm{B}, \mathrm{C}$, and $\mathrm{D}$ based on the diffractogram were silica (quartz), dolomite, kaolinite, lawsonite, and muscovite. Meanwhile, the major mineral composition in the Fukushima soils were silica (quartz), kaolinite, lawsonite, and muscovite. Kaolinite was one of the minerals that would bond strongly with cesium [12]. Therefore, in this regard, the soil from Kotagede was quite like Fukushima soil. The soil properties of Kotagede and Fukushima were summarized, as shown in Table 1.

\section{Distribution of $\mathrm{pH}$ after EKR Treatment}

The application of direct current via electrodes resulted in oxidation at the anode, generating the acid front, while reduction at the cathode produced a base front as shown by Eq. (1) and Eq. (2). Therefore, oxidation and reduction in the electrode resulted in the $\mathrm{pH}$ profiles during the EKR treatment. The initial $\mathrm{pH}$ of soil A, B, C, and D were 7.7, 7.8, 6.9, 7.4, respectively. Fig. 2 shows the distribution of soil $\mathrm{pH}$ when $\mathrm{HNO}_{3}$ and
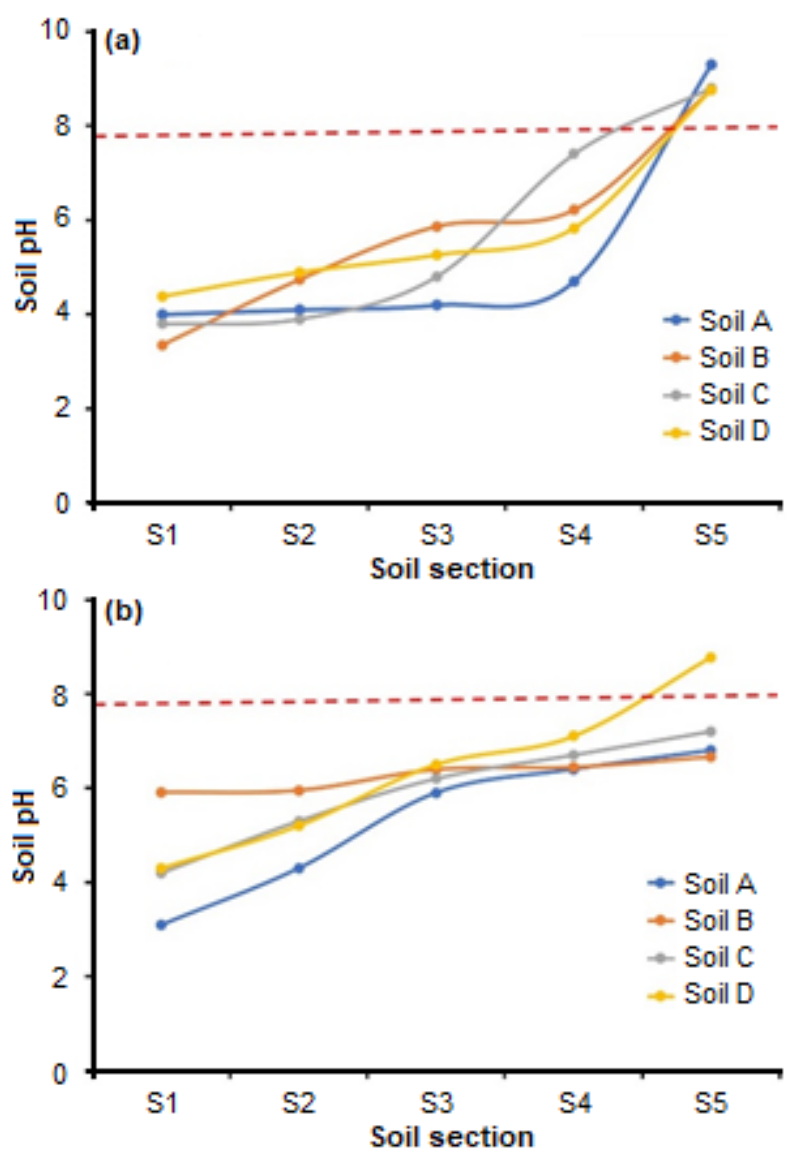

Fig 2. Soil $\mathrm{pH}$ profiles in after EKR used 1.0 $\mathrm{M} \mathrm{HNO}_{3}$ (a) and $\mathrm{CH}_{3} \mathrm{COOH}$ (b) as electrolyte. S1 was compartment near the anode and S5 was compartment near the cathode. The red line indicated the initial pH in the soil before EKR treatment 
Table 1. Soil Characterization of Kotagede and Fukushima

\begin{tabular}{|c|c|c|c|c|c|c|c|}
\hline \multirow{2}{*}{\multicolumn{2}{|c|}{ Parameters }} & \multicolumn{4}{|c|}{ Kotagede soils } & \multirow{2}{*}{\multicolumn{2}{|c|}{$\begin{array}{l}\text { Fukushima soil } \\
\text { (Kawamata) }\end{array}$}} \\
\hline & & Soil A & Soil B & Soil C & Soil D & & \\
\hline \multicolumn{8}{|c|}{ Particle size distribution (\%): } \\
\hline \multirow{3}{*}{\multicolumn{2}{|c|}{$\begin{array}{l}\text { Sand } \\
\text { Silt } \\
\text { Clay }\end{array}$}} & 66.43 & 64.35 & 51.84 & 68.16 & \multicolumn{2}{|l|}{83.4} \\
\hline & & 23.09 & 24.35 & 36.05 & 23.68 & \multicolumn{2}{|l|}{8.8} \\
\hline & & 10.48 & 11.31 & 12.11 & 8.16 & \multicolumn{2}{|l|}{7.8} \\
\hline \multicolumn{2}{|l|}{ Soil texture } & $\begin{array}{l}\text { Sandy } \\
\text { loam }\end{array}$ & $\begin{array}{l}\text { Sandy } \\
\text { loam }\end{array}$ & $\begin{array}{l}\text { Sandy } \\
\text { loam }\end{array}$ & $\begin{array}{l}\text { Sandy } \\
\text { loam }\end{array}$ & \multicolumn{2}{|c|}{ Sandy loam } \\
\hline & 0.83 & 1.64 & 1.47 & 4.27 & \multicolumn{2}{|l|}{0.74} \\
\hline \multicolumn{2}{|l|}{ Organic matter (\%) } & 1.43 & 2.83 & 2.54 & 4.27 & \multicolumn{2}{|c|}{$3.91(\mathrm{~g} / \mathrm{kg})$} \\
\hline \multicolumn{2}{|l|}{ Total N (\%) } & 0.09 & 0.05 & 0.11 & 0.14 & \multicolumn{2}{|l|}{$0.8(\mathrm{~g} / \mathrm{kg})$} \\
\hline & 12.35 & 16.83 & 18.06 & 16.95 & \multicolumn{2}{|c|}{$9(\mathrm{cmol} / \mathrm{kg})$} \\
\hline \multicolumn{2}{|l|}{$\mathrm{pH}(1: 20, \mathrm{w} / \mathrm{v})$} & 7.7 & 7.8 & 6.9 & 7.4 & \multicolumn{2}{|c|}{$6.32(1: 5)$} \\
\hline \multirow{2}{*}{\multicolumn{2}{|c|}{$\begin{array}{l}\text { Surface area, } \mathrm{m}^{3} / \mathrm{g} \\
\text { Pore volume, } \mathrm{m}^{3} / \mathrm{g}\end{array}$}} & 25.67 & 35.10 & 40.69 & 28.46 & \multicolumn{2}{|l|}{-} \\
\hline & & 52.37 & 64.02 & 64.11 & 50.17 & - & \\
\hline \multirow{2}{*}{ Mineral composition: } & \multirow{2}{*}{$2 \theta$} & & & & & \multicolumn{2}{|c|}{ Fukushima soil $^{\mathrm{b}}$} \\
\hline & & & & & & $\mathrm{K}$ & $\mathrm{M}$ \\
\hline Silica (quartz) & $\begin{array}{l}21,800-21,900 \\
27,700-27,750 \\
49,600-49,850 \\
67,500-67,900 \\
\end{array}$ & $\begin{array}{l}\text { Minor } \\
(3.0 \%)\end{array}$ & $\begin{array}{l}\text { Major } \\
(12.9 \%)\end{array}$ & $\begin{array}{l}\text { Minor } \\
(2.3 \%)\end{array}$ & $\begin{array}{l}\text { Minor } \\
(3.4 \%)\end{array}$ & $\begin{array}{l}\text { Major } \\
(49.6 \%)\end{array}$ & $\begin{array}{l}\text { Major } \\
(25.5 \%)\end{array}$ \\
\hline Dolomite & $\begin{array}{l}31,500 \\
42,150 \\
52,270 \\
\end{array}$ & $\begin{array}{l}\text { Minor } \\
(4.4 \%)\end{array}$ & $\begin{array}{l}\text { Major } \\
(7.1 \%)\end{array}$ & $\begin{array}{l}\text { Minor } \\
(2.4 \%)\end{array}$ & $\begin{array}{l}\text { Major } \\
(5.5 \%)\end{array}$ & $\begin{array}{l}\text { Minor } \\
(4.1 \%)\end{array}$ & $\begin{array}{l}\text { Minor } \\
(4.9 \%)\end{array}$ \\
\hline Ilmenite & $\begin{array}{l}35,540-35,680 \\
48,350-48,420 \\
62,240-62,320 \\
\end{array}$ & $\begin{array}{l}\text { Minor } \\
(4.2 \%)\end{array}$ & $\begin{array}{l}\text { Major } \\
(6.3 \%)\end{array}$ & $\begin{array}{l}\text { Minor } \\
(5.0 \%)\end{array}$ & $\begin{array}{l}\text { Minor } \\
(3.9 \%)\end{array}$ & $\begin{array}{l}\text { Minor } \\
(1.9 \%)\end{array}$ & $\begin{array}{l}\text { Minor } \\
(3.3 \%)\end{array}$ \\
\hline Franklinite & $30,320-30,330$ & $\begin{array}{l}\text { Minor } \\
(2.3 \%) \\
\end{array}$ & $\begin{array}{l}\text { Minor } \\
(3.3 \%) \\
\end{array}$ & $\begin{array}{l}\text { Minor } \\
(1.4 \%) \\
\end{array}$ & $\begin{array}{l}\text { Minor } \\
(3.5 \%) \\
\end{array}$ & $\begin{array}{l}\text { Minor } \\
(1.3 \%) \\
\end{array}$ & $\begin{array}{l}\text { Minor } \\
(1.7 \%) \\
\end{array}$ \\
\hline Kaolinite & $23,640-23,690$ & $\begin{array}{l}\text { Major } \\
(16.2 \%) \\
\end{array}$ & $\begin{array}{l}\text { Major } \\
(23.5 \%) \\
\end{array}$ & $\begin{array}{l}\text { Major } \\
(8.8 \%) \\
\end{array}$ & $\begin{array}{l}\text { Major } \\
(10.9 \%) \\
\end{array}$ & $\begin{array}{l}\text { Major } \\
(20.3 \%) \\
\end{array}$ & $\begin{array}{l}\text { Major } \\
(32.2 \%) \\
\end{array}$ \\
\hline Lawsonite & $42,360-42,960$ & $\begin{array}{l}\text { Major } \\
(14.1 \%) \\
\end{array}$ & $\begin{array}{l}\text { Major } \\
(16.5 \%) \\
\end{array}$ & $\begin{array}{l}\text { Major } \\
(7.5 \%) \\
\end{array}$ & $\begin{array}{l}\text { Major } \\
(9.2 \%) \\
\end{array}$ & $\begin{array}{l}\text { Major } \\
(10.7 \%)\end{array}$ & $\begin{array}{l}\text { Major } \\
(11.7 \%) \\
\end{array}$ \\
\hline Goethite & $\begin{array}{l}34,960 \\
53,370 \\
\end{array}$ & $\begin{array}{l}\text { Minor } \\
(1.6 \%) \\
\end{array}$ & $\begin{array}{l}\text { Minor } \\
(3.7 \%) \\
\end{array}$ & $\begin{array}{l}\text { Minor } \\
(1.1 \%) \\
\end{array}$ & $\begin{array}{l}\text { Minor } \\
(2.3 \%) \\
\end{array}$ & $\begin{array}{l}\text { Minor } \\
(2.5 \%) \\
\end{array}$ & $\begin{array}{l}\text { Minor } \\
(4.3 \%) \\
\end{array}$ \\
\hline Pyrolusite & $\begin{array}{l}57,360 \\
29,790 \\
\end{array}$ & $\begin{array}{l}\text { Minor } \\
(5.0 \%) \\
\end{array}$ & $\begin{array}{l}\text { Major } \\
(8.9 \%) \\
\end{array}$ & $\begin{array}{l}\text { Minor } \\
(3.1 \%)\end{array}$ & $\begin{array}{l}\text { Minor } \\
(4.7 \%) \\
\end{array}$ & $\begin{array}{l}\text { Trace } \\
(0.4 \%)\end{array}$ & $\begin{array}{l}\text { Minor } \\
(2.5 \%) \\
\end{array}$ \\
\hline Muscovite & 28,450 & $\begin{array}{l}\text { Major } \\
(48.0 \%) \\
\end{array}$ & $\begin{array}{l}\text { Major } \\
(11.3 \%) \\
\end{array}$ & $\begin{array}{l}\text { Major } \\
(67.8 \% \\
\end{array}$ & $\begin{array}{l}\text { Major } \\
(55.4 \%) \\
\end{array}$ & $\begin{array}{l}\text { Major } \\
(6.0 \%) \\
\end{array}$ & $\begin{array}{l}\text { Major } \\
(7.3 \%) \\
\end{array}$ \\
\hline Anatase & 27,730 & $\begin{array}{l}\text { Minor } \\
(1.2 \%) \\
\end{array}$ & $\begin{array}{l}\text { Trace } \\
(0.9 \%) \\
\end{array}$ & $\begin{array}{l}\text { Trace } \\
(0.7 \%) \\
\end{array}$ & $\begin{array}{l}\text { Minor } \\
(1.1 \%) \\
\end{array}$ & $\begin{array}{l}\text { Minor } \\
(2.5 \%) \\
\end{array}$ & $\begin{array}{l}\text { Major } \\
(6.2 \%) \\
\end{array}$ \\
\hline
\end{tabular}

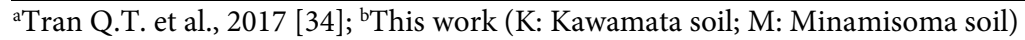

$\mathrm{CH}_{3} \mathrm{COOH}$ were used as an electrolyte. It shows that each $\mathrm{pH}$ soil increased by the distance from anode to cathode (e.g., from $\mathrm{S} 1$ to S5) in the range from 3 to 7 . These results are in accordance with the findings reported in various studies [13-14].

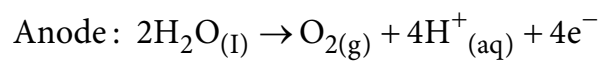

Cathode: $2 \mathrm{H}_{2} \mathrm{O}_{(\mathrm{I})}+2 \mathrm{e}^{-} \rightarrow \mathrm{H}_{2(\mathrm{~g})}+2 \mathrm{OH}^{-}{ }_{(\mathrm{aq})}$

Generally, the acid front can enhance the desorption of cesium from soil and dissolve the cesium ions, causing the ions to freely move through the soil and ideally to the cathode reservoir where they can be removed. Meanwhile, alkaline front significantly 
declined the mobility of the cesium ions because of the metal hydroxide precipitation, thereby immobilizing the metals before they reach the cathode. The soil $\mathrm{pH}$ increased from anode to the cathode at more than 6.8. This is a typical soil $\mathrm{pH}$ profile for EKR treatment [15-16]. The soil $\mathrm{pH}$ near to the cathode sharply increased to above the initial soil $\mathrm{pH}$ when using $\mathrm{HNO}_{3}$ as the electrolyte. However, there was no significant $\mathrm{pH}$ increase in the soil when $\mathrm{CH}_{3} \mathrm{COOH}$ was used as the electrolyte.

High acidification of the remaining soil after the EKR treatment caused the loss of base cations, nonreversible clay mineral dissolution, and a reduction in cation exchange capacity, accompanied by structural deterioration [17]. In agriculture, simple treatment of soil acidity is ameliorated by applying lime or other unconventional acid-neutralizing materials such as rice husk ash [18], wood ash [19], and steel slag [20]. In addition, to neutralize the acid, sometimes ecologically sound remediation of acidic soil using bicarbonate-rich swine wastewater [21] and marble wastes are also used [22].

\section{Cesium Concentration after EKR Treatment}

Generally, the remaining cesium concentration in all soils was lower than the initial concentration $(100 \mathrm{mg} / \mathrm{kg})$ with a varied concentration. Fig. 3 shows that the remaining cesium concentration was much lower in soil A (from 49.14 to $89.34 \mathrm{mg} / \mathrm{kg}$ ) and soil C (from 35.05 to $85.41 \mathrm{mg} / \mathrm{kg}$ ) than that in soil B (from 55.18 to $101.89 \mathrm{mg} / \mathrm{kg}$ ) and soil D (from 25.30 to $87.25 \mathrm{mg} / \mathrm{kg}$ ) when $\mathrm{HNO}_{3}$ was used as the electrolyte. Meanwhile, when $\mathrm{CH}_{3} \mathrm{COOH}$ was used as the electrolyte, the remaining cesium concentration in the soil was as much as 32.34 to $105.41 \mathrm{mg} / \mathrm{kg}, 45.41$ to $69.92 \mathrm{mg} / \mathrm{kg}, 55.64$ to $96.65 \mathrm{mg} / \mathrm{kg}$ and 78.35 to $95.63 \mathrm{mg} / \mathrm{kg}$ for soil A, C, B and D respectively. The removal of cesium in soil $A$ and $C$ was much higher than the removal of cesium in soil $\mathrm{B}$ and $\mathrm{D}$, even though a strong acid like $\mathrm{HNO}_{3}$ was used as an electrolyte. This can occur because the soils have a low buffering capacity against acid. Previously reported results showed that soils $\mathrm{B}$ and $\mathrm{D}$ have a low buffering capacity against base [10]. Therefore, soils $B$ and D are relatively easy to alkalinize compared to soils A and C. In addition, during the EKR treatment, the low $\mathrm{pH}$ (i.e., acid) near the anode can promote more $\mathrm{Cs}^{+}$ions from the soil into the pore fluid, enabling the ions to be transported by electromigration. Thus, high removal of cesium from soil was observed near the anode. On the contrary, the high $\mathrm{pH}$ in the soil near the cathode (e.g., alkaline) was associated with metal hydroxide $(\mathrm{MeOH})$ in the pore fluid that hindered the removal of cesium from soil. High amounts of heavy metals are retained in the soil when the buffer capacity is high enough to resist a change under the alkaline condition [23].

Most of the Cs have remained on the surface of the soil because the Cs ions were strongly adsorbed in the interlayer spaces of the clay soil, aluminosilicate sheet structures, particularly the vermiculite [24-25]. The treatment on the removal of cesium from contaminated soil depends on the penetration depth of the cesium in the soil, which is influenced by the soil characteristics such as clay content, particle size, and organic carbon content [26]. If the soil had vermiculite content, the migration efficiency of Cs ions in the EKR treatment decreased as the vermiculite content increased because the Cs ions can easily enter the interlayer of the basal spacing [27]. The observation of the changed structure of the vermiculite in aqueous suspension was measured by small-angle X-ray and it showed that the abruption of the clay sheets was induced by the localization of Cs ions at the interlayer clay structure [28]. In addition, the removal efficiency of cesium using EKR in the radioactive soil decreased somewhat due to the aging effect [29].

\section{Electric Current Profiles}

Fig. 4(a) and 4(b) show the current profiles across the soil in the EKR experiments with $\mathrm{HNO}_{3}$ and $\mathrm{CH}_{3} \mathrm{COOH}$ as the electrolyte. How much the metal ions moved by electromigration in the pore fluid during the EKR process can be shown by the current profiles [30]. As seen in Fig. 4, the current increased in the first few days and then declined, finally remaining stable. Stable currents in all experiments was obtained depending on the migration rates of ions from the pore fluid in the soil [31]. Generally, the current reached a peak near or at the start of the experiment when the number of ions in the 

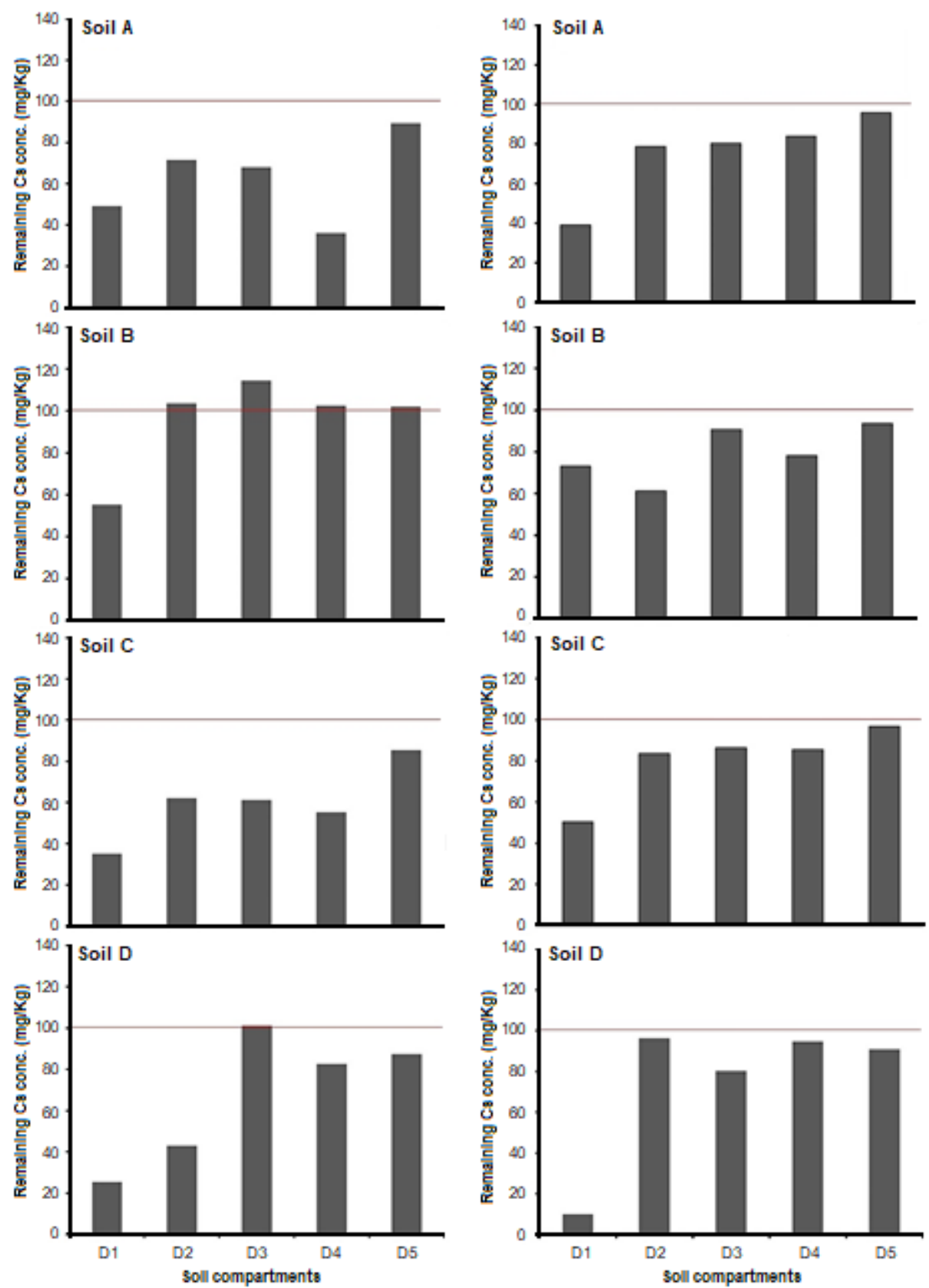

(a)

(b)

Fig 3. Remaining Cs concentration in the soil $\mathrm{A}, \mathrm{B}, \mathrm{C}$ and $\mathrm{D}$ after EKR process when used $1.0 \mathrm{M} \mathrm{HNO}_{3}$ (a) and $\mathrm{CH}_{3} \mathrm{COOH}(\mathrm{b})$ as electrolyte. The component near to the anode is D1 and the component near to the cathode is D5. The red line indicated the initial concentration of Cs in the soil before EKR treatment

pore fluid was high due to dissolved ions associated with dry soil particles. As the ions electromigrated towards the electrodes, the current gradually declined as similarly reported in several publications [30-32].

Fig. 4(a) shows the current profile when $\mathrm{HNO}_{3}$ was used as the electrolyte. Nitric acid in the solution produced high amounts of $\mathrm{H}^{+}$ions, which moved toward the cathode. Consequently, the soil was acidified, which in turn promoted the desorption of cesium ions into the pore fluid. As a result, the current crossing in the soil increased rapidly, then declined and reached a stable current (see Fig. 4(a)). The phenomenon can be 

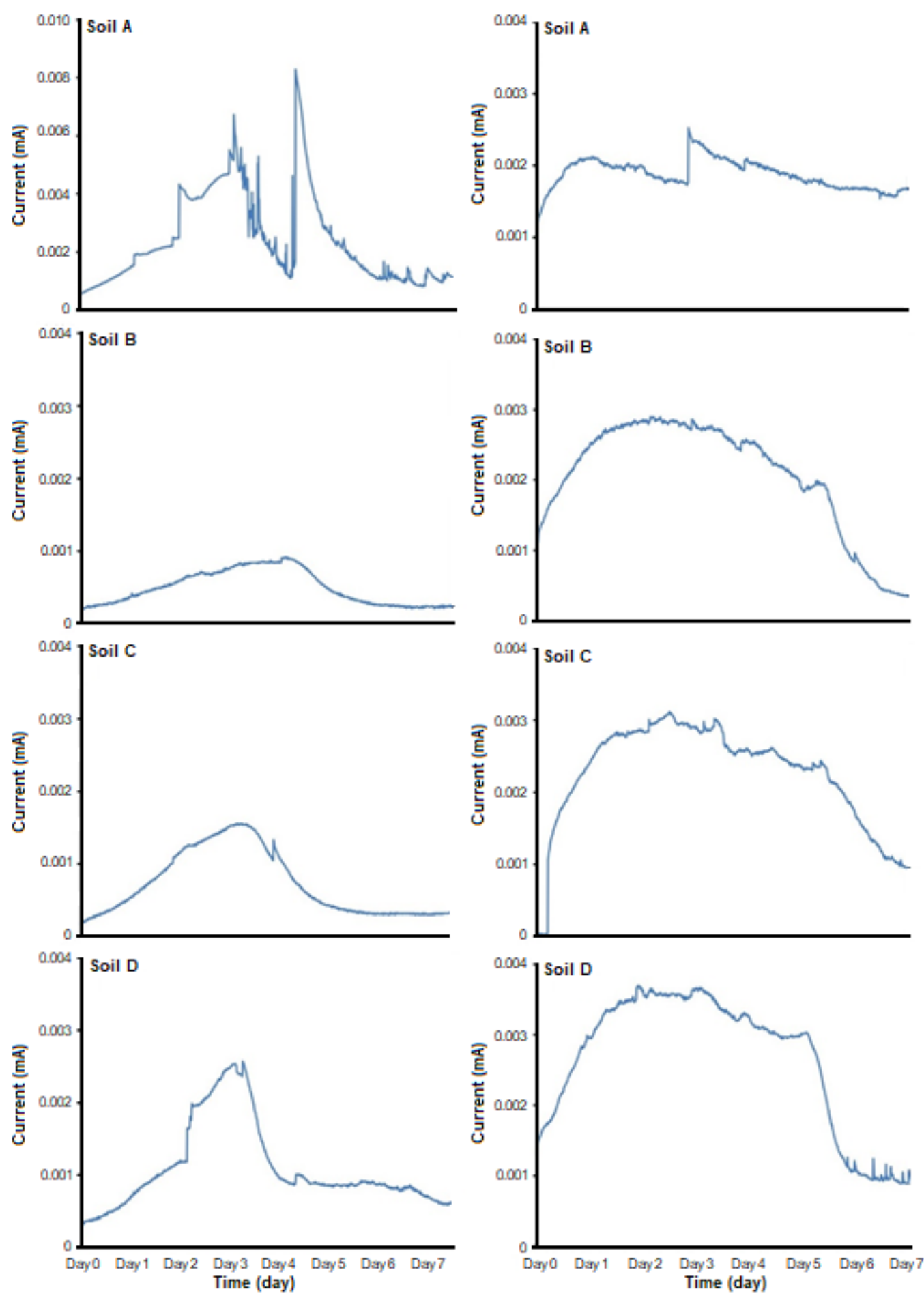

(a)

(b)

Fig 4. Current profiles during the $\mathrm{EK}$ remediation using $0.1 \mathrm{M} \mathrm{HNO}_{3}(\mathrm{~A})$ and $\mathrm{CH}_{3} \mathrm{COOH}(\mathrm{B})$ as the electrolyte

explained by two reasons; (i) resistance at the interface between the electrodes and the electrolyte might have increased because of the concentration polarization and water dissociation in the electrolysis and (ii) ions with positive or negative charges moved to the two ends of the electric cell (e.g., anode and cathode), which resulted in the drop of the ionic strength in the soils and the current as well [33]. This phenomenon occurs when a strong 
acid like $\mathrm{HNO}_{3}$ undergoes complete dissociation to $\mathrm{NO}_{3}{ }^{-}$ and $\mathrm{H}^{+}$ions, as shown in Eq. (3). However, reversible dissociation occurs when weak organic acids like $\mathrm{CH}_{3} \mathrm{COOH}$ is applied as an electrolyte, as shown in Eq. (4). Therefore, the current profile was high-broad, which indicates that the soil resistance was high (see Fig. 4(b)).

$$
\begin{aligned}
& \mathrm{HNO}_{3(\mathrm{aq})} \rightarrow \mathrm{NO}_{3}{ }_{(\mathrm{aq})}+\mathrm{H}^{+}{ }_{(\mathrm{aq})} \\
& \mathrm{CH}_{3} \mathrm{COOH}_{(\mathrm{aq})} \leftrightarrow \mathrm{CH}_{3} \mathrm{COO}^{-}{ }_{(\mathrm{aq})}+\mathrm{H}^{+}{ }_{(\mathrm{aq})}
\end{aligned}
$$

The acidic solution enhanced the desorption of ions from the soil into the pore fluid so that the high concentration of ions in the pore fluid increased the electric current under a constant voltage condition. However, a higher current led to high power consumption.

\section{- CONCLUSION}

According to the results of the experiments, the following conclusion can be stated briefly. The soil samples from Kotagede, Yogyakarta, Indonesia have a similar physico-chemical properties with the contaminated soils from Fukushima, Japan, in terms of soil texture, soil properties, and mineral content. In this regard, the major mineral content was silica (quartz) and kaolinite, and the soil texture was sandy loam. The soil $\mathrm{pH}$ near the cathode sharply increased to above the initial soil $\mathrm{pH}$ when using $\mathrm{HNO}_{3}$ as the electrolyte. However, there was no significant $\mathrm{pH}$ increase in the soil when $\mathrm{CH}_{3} \mathrm{COOH}$ was used as the electrolyte. High soil $\mathrm{pH}$ occurred near the cathode, indicating the precipitation of cesium ions in the cathode area. The removal of cesium from soils were highly effective when $\mathrm{HNO}_{3}$ was used as the electrolyte. However, the order of the highest to lowest cesium removal in the soil for all acids (e.g., $\mathrm{HNO}_{3}$ and $\mathrm{CH}_{3} \mathrm{COOH}$ ) were as follows: soils $\mathrm{C}>\mathrm{A}>\mathrm{D}>\mathrm{B}$. The current profiles in the EKR treatment showed that $\mathrm{HNO}_{3}$ as an electrolyte was undergoing complete dissociation, which caused a low resistance in the soil showed by a low current plateau. Meanwhile, $\mathrm{CH}_{3} \mathrm{COOH}$ as a weak acid undergoes partial dissociation, which caused a high resistance in the soil during EKR treatment, producing a high current plateau.

\section{- ACKNOWLEDGMENTS}

The authors would like to thank the Ministry of Education and Culture and the Ministry of Research and Technology of the Republic of Indonesia for their financial support through the Excellence Higher Education Basic Research (PDUPT) 2019-2020 (Research contract: B/1436.1/L5/DRA.00/2019; LLDIKTI and UII contract: 1627.1/LL5/PG/2020). Financial support from the Directorate of Talent Development and Student Welfare of Universitas Islam Indonesia to N.Z.J. and A.I.A. are also gratefully acknowledged.

\section{- REFERENCES}

[1] Ariyanto, S., and Widodo, W.L., 2014, Status of Nuclear Power Plant Development in Indonesia, Center for Nuclear Energy Development (BATAN), Jakarta.

[2] Sriyana, 2012, Current Status of Indonesia's Nuclear Power Program, IAEA Technical Meeting/Workshop on Topical Issues on Infrastructure Development: Managing the Development of National Infrastructure for NPPP, Vienna, Austria, 24-27 January 2012.

[3] Mao, X., Han, F.X., Shao, X., Guo, K., McComb, J., Arslan, Z., and Zhang, Z., 2016, Electro-kinetic remediation coupled with phytoremediation to remove lead, arsenic and cesium from contaminated paddy soil, Ecotoxicol. Environ. Saf., $125,16-24$.

[4] Ding, D., Zhang, Z., Lei, Z., Yang, Y., and Cai, T., 2016, Remediation of radiocesium-contaminated liquid waste, soil, and ash: A mini review since the Fukushima Daiichi Nuclear Power Plant accident, Environ. Sci. Pollut. Res., 23 (3), 2249-2263.

[5] Evrard, O., Laceby, J.P., and Nakao, A., 2019, Effectiveness of landscape decontamination following the Fukushima nuclear accident: A review, Soil, 5, 333-350.

[6] Shukla, A., Parmar, P., and Saraf, M., 2017, Radiation, radionuclides and bacteria: An inperspective review, J. Environ. Radioact., 180, 27-35. 
[7] Zhao, C., Dong, Y., Feng, Y., Lia, Y., and Dong, Y., 2019, Thermal desorption for remediation of contaminated soil: A review, Chemosphere, 221, 841855.

[8] Chu, C.Y., and Ko, T.H., 2018, Evaluation of acid leaching on the removal of heavy metals and soil fertility in contaminated soil, J. Chem., 2018, 5036581.

[9] Acar, Y.B., and Alshawabkeh, A.N., 1993, Principles of electrokinetic remediation, Environ. Sci. Technol., 27 (13), 2638-2647.

[10] Putra, R.S., Budiarjo, S., and Yendi, N., 2016, Removal characteristics of silver with electrokinetic by adsorption on soil mineral from Kotagede Yogyakarta, Proceeding of $3^{\text {rd }}$ International Conference on Research, Implementation and Education of Mathematics and Science, Universitas Negeri Yogyakarta, Yogyakarta, Indonesia, 16-17 May 2016.

[11] Pratama, K., 2016, Karakterisasi tanah kotagede terhadap adsorpsi logam perak (Ag): Remediasi logam perak (Ag) dengan metode elektrokinetik menggunakan elektrolit asam asetat, Undergraduate Thesis, Department of Chemistry, Faculty of Mathematics and Natural Sciences, Universitas Islam Indonesia, Yogyakarta, Indonesia.

[12] Durrant, C.B., Begg, J.D., Kersting, A.B., and Zavarin, M., 2018, Cesium sorption reversibility and kinetics on illite, montmorillonite, and kaolinite, Sci. Total Environ., 610-611, 511-520.

[13] Bahemmat, M., and Farahbakhsh, M., 2015, Catholyte-conditioning enhanced electrokinetic remediation of $\mathrm{Co}-$ and $\mathrm{Pb}$ polluted soil, Environ. Eng. Manage. J., 14 (1), 89-96.

[14] Kim, G.N., Yang, B.I., Choi, W.K., Lee, K.W., and Hyeon, J.H., 2009, Washing-electrokinetic decontamination for concrete contaminated with cobalt and cesium, Nucl. Eng. Technol., 41 (8), 10791086.

[15] Huang, T., Li, D., Kexiang, L., and Zhang, Y., 2015, Heavy metal removal from MSWI fly ash by electrokinetic remediation coupled with a permeable activated charcoal reactive barrier, Sci. Rep., 5 (1), 15412.

[16] Arbai, S., Mohamed, Z., Mohamed, K., and Bakar, A.A., 2014, "Electrokinetic remediation to remove heavy metal from contaminated soils using purging solution"in InCIEC 2013, Eds. Hassan, R., Yussof, M., Ismail, Z., Amin, N., and Fadzil, M., Springer, Singapore, 531-538.

[17] Goulding, K.W.T., 2016, Soil acidification and the importance of liming agricultural soils with particular reference to the United Kingdom, Soil Use Manage., 32 (3), 390-399.

[18] Islabão, G.O., Vahl, L.C., Timm, L.C., Paul, D.L., and Kath, A.H., 2014, Rice husk ash as corrective of soil acidity, Rev. Bras. Ciênc. Solo, 38 (3), 934-941.

[19] Ohno, T., 1992, Neutralization of soil acidity and release of phosphorus and potassium by wood ash, J. Environ. Qual., 21 (3), 433-438.

[20] Plopeanu, G., Gamenţ, E., Marinescu, M., Vrînceanu, N., and Carabulea, V., 2017, Steel slag Unconventional amendment for acid soils, AgroLife Sci. J., 6 (1), 195-200.

[21] Qilu, C., Xueling, W, ligen X, Hui, L., Yuhua, Z., and Qifa, Z., 2017, High-quality, ecologically sound remediation of acidic soil using bicarbonate-rich swine wastewater, Sci. Rep., 7 (1), 11911.

[22] Tozsin, G., Arol, A.I., Oztas, T., and Kalkan, E., 2014, Using marble wastes as a soil amendment for acidic soil neutralization, J. Environ. Manage., 133, 374-377.

[23] Villen-Guzman, M., Paz-Garcia, J.M., AmayaSantos, G., Rodriguez-Maroto, J.M., VeredaAlonso, C., and Gomez-Lahoz, C., 2015, Effects of the buffering capacity of the soil on the mobilization of heavy metals. Equilibrium and kinetics, Chemosphere, 131, 78-84.

[24] Kato, H., Onda, Y., and Teramage, M., 2012, Depth distribution of ${ }^{137} \mathrm{Cs},{ }^{134} \mathrm{Cs}$, and ${ }^{131} \mathrm{I}$ in soil profile after Fukushima Dai-ichi Nuclear Power Plant accident, J. Environ. Radioactiv., 111, 59-64.

[25] Kaneko, M., Iwata, H., Shiotsu, H., Masaki, S., Kawamoto, Y, Yamasaki, S., Nakamatsu, Y., Imoto, 
J., Furuki, G., Ochiai, A, Nanba, K., Ohnuki, T., Ewing, R.C., and Utsunomiya, S., 2015, Radioactive Cs in the severely contaminated soils near the Fukushima Daiichi Nuclear Power Plant, Front. Energy Res., 3, 37.

[26] Ochi, K., Sasaki, M., Ishida, M., Hamamoto, S., Nishimura, T., and Sanada, Y., 2017, Estimation of the vertical distribution of radiocesiumin soil on the basis of the characteristics of gamma-ray spectra obtained via aerial radiation monitoring using an unmanned helicopter, Int. J. Environ. Res. Public Health, 14 (8), 926.

[27] Akemoto, Y., Kan, M., and Tanaka, S., 2019, Static adsorption of cesium ions on kaolin/vermiculite and dynamic adsorption/desorption using electrokinetic process, J. Chem. Eng. Jpn., 52 (7), 662-669.

[28] Motokawa, R., Endo, H., Yokoyama, S., Nishitsuji, S., Kobayashi, T., Suzuki, S., and Yaita, T., 2015, Collective structural changes in vermiculite clay suspensions induced by cesium ions, Sci. Rep., 4 (1), 6585.

[29] Kim, G.N., Oh, W.Z., Won, H.Z., and Jung, C.H., 2004, An analysis of the aging effect on the removal of cesium and cobalt from radioactive soil by the electrokinetic method, J. Korean Nucl. Soc., 36 (4), 304-315.

[30] Putra, R.S., and Tanaka, S., 2011, Aluminum drinking water treatment residuals (Al-WTRs) as an entrapping zone for lead in soil by electrokinetic remediation, Sep. Purif. Technol., 79 (2), 208-215.

[31] Zhang, T., Zou, H., Ji, M., Li, X., Li, L., and Tang, T., 2014, Enhanced electrokinetic remediation of leadcontaminated soil by complexing agents and approaching anodes, Environ. Sci. Pollut. Res., 21 (4), 3126-3133.

[32] Ng, Y.S., Gupta, B.S., and Hashim, M.A., 2016, Remediation of $\mathrm{Pb} / \mathrm{Cr}$ co-contaminated soil using electrokinetic process and approaching electrode techniques, Environ. Sci. Pollut. Res., 23 (1), 546555.

[33] Acar, Y.B., and Alshawabkeh, A.N., 1996, Electrokinetic remediation. I: Pilot-scale tests with lead-spiked kaolinite, J. Geotech. Eng., 122 (3), 173185.

[34] Tran, Q.T., Maeda, M., Oshita, K., and Takaoka, M., 2017, Phosphorus release from cattle manure ash as soil amendment in laboratory-scale tests, Soil Sci. Plant Nutr., 63 (4), 369-376. 